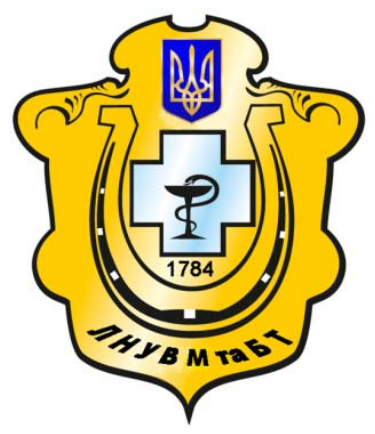

Науковий вісник Львівського національного університету ветеринарної медицини та біотехнологій імені С.3. Гжицького

Scientific Messenger of Lviv National University of Veterinary Medicine and Biotechnologies named after S.Z. Gzhytskyj

doi:10.15421/nvlvet7137

ISSN 2413-5550 print

ISSN 2518-1327 online

$\underline{\text { http://nvlvet.com.ua/ }}$

УДК 604.6.001.11:633.002.6: 354.35

\title{
Контроль генетично модифікованих рослин - гарантія продовольчої безпеки
}

\author{
Г.В. Кушнір \\ galmwi@ukr.net
}

Державний науково-дослідний контрольний інститут ветеринарних препаратів та кормових добавок, вул. Донецька, 11, Львів, 79019, Україна

\begin{abstract}
У статті проаналізовано дослідження, які були проведені щзоо визначення генетично модифікованих організмів в рослинній сировині за період 2013 - 2015 рр., від господарств різної форми власності. Аналіз проведених досліджень вказує на ииркуляиію в господарствах Львівської області трансгенних рослин. Встановлено, щзо найбільш поширеними генетично модифікованими рослинами були кукурудза, соя та ріпак. Дослідження рослинної сировини на наявність ГМО проводили методом полімеразної ланцюгової реакиії у режимі реального часу (ПЛР-РЧ) иляхом встановлення в них иільових послідовностей промотора 35 в вірусу мозаїки цвітної капусти (СаMV), промотора FMV і (або) термінатора NOS (T-NOS) T1 плазміди Agrobacterium tumefaciens, Pat, EPSPS, Cry 3A, а також проведено видову ідентифікаиію позитивних зразків. Використання ПЛР-РЧ дає можливість швидко і якісно виявити ГМО в досліджуваних зразках. У 2013 роиі відсоток позитивних проб становив 3,9\% від загальної кількості, у 2014 роия - 2,3\%, у 2015 роия - 3,3\%. Тому необхідно проводити моніторинг рослинної сировини та посівного матеріалу на наявність генетично модифікованих організмів, щоб простежити ситуацію, яка склалася в Украӥні щзодо ГМО, оскільки проблема біобезпеки і оцінки потенційних ризиків від їх використання ще остаточно не вивчена.

Ключові слова: безпека рослинної сировини, генетично модифіковані організми, трансгенні рослини, біотехнологія, полімеразно-ланцюгова реакція, ПЛР РЧ.
\end{abstract}

\section{Контроль генетически модифицированных растений - гарантия продовольственной безопасности}

\author{
Г.В. Кушнир \\ galmwi@ukr.net
}

Государственный научно-исследовательский контрольный институт ветеринарных препаратов и кормовых добавок, ул. Донеикая, 11, г. Львов, 79019, Украина

\begin{abstract}
В статье проанализированы исследования, проведенные по определению генетически модифицированных организмов в растительном сырье за период 2013 - 2015 г2., от хозяйств различной формы собственности. Анализ проведенных исследований указывает на ицркуляцию в хозяйствах Львовской области трансгенных растений. Установлено, что наиболее распостраненными генетически модифицированными растениями были кукуруза, соя и рапс. Исследование растительного сырья на наличие ГМО проводили методом полимеразной иепной реакиии в режиме реального времени (ПЦР-РЧ) путем установления в них цеелевых последовательностей промотора $35 S$ вируса мозаики иветной капусть (СаMV), промотора FMV и (или) терминатора NOS (T-NOS) T1 плазмиды Agrobacterium tumefaciens, Pat, EPSPS, Cry 3A, а так же провели видовую идентификацию положительных образиов. Использование ПЦР-РЧ дает возможность быстро и качественно вылвить ГМО в исследуемых образиах. В 2013 году процент положительных проб составлял 3,9\% от общего количества, в 2014 году -2,3\%, в 2015 году - 3,3\%. Поэтому необходимо проводить мониторинг растительного сырья и посевного материала на наличие генетически модифичированных организмов, чтобы проследить ситуачию, которая сложилась в Ук-
\end{abstract}

Citation:

Kushnir, G.V. (2016). The control of genetically modified plants - guarantee of food safety. Scientific Messenger LNUVMBT named after S.Z. Gzhytskyj, 18, 3(71), 167-169. 
раине относительно ГМО, поскольку проблема биобезопасности и оченки потенциальных рисков от их использования еще окончательно не изучена.

Ключевые слова: безопасность растительного сырья, генетически модифицированные организмы, трансгенные растения, биотехнология, полимеразная цеепная реакичя, ПЦР РВ.

\title{
The control of genetically modified plants - guarantee of food safety
}

\author{
G.V. Kushnir \\ galmwi@ukr.net \\ State Scientific-Research Control Institute of Veterinary Medicinal Products and Feed Additives, \\ Donetska Str., 11, Lviv 79019, Ukraine
}

\begin{abstract}
One of the problems in formation of mechanisms of development of environmentally safe environment is the proliferation of genetically modified organisms (GMOs). The use of genetic engineering in agriculture, food and agricultural industry have created the new opportunities for manufacturing the food and feed for meet the ever growing needs of the world's population. However, the opinions of scientists about the benefits and risks of genetic engineering is different. So today is particularly acute issue unpredictable consequences and danger for human health and the environment which are connected with GMO.

The article present the results of determination of genetically modified organisms in plant material for the period 2013 2015 years, from the farms of different ownership forms. Analysis of the conducted research indicates on the circulation in farms of Lviv region transgenic plants.Found that the most common genetically modified plants were maize, soya and rape. The research of plant material on the presence of GMOs was performed by polymerase chain reaction in real time (PCR RF) by setting in them target sequences of promoter $35 S$ virus of cauliflower mosaic (CaMV), promoter of FMV and (or) terminator NOS (T-NOS) T1 plasmid of Agrobacterium tumefaciens, Pat, EPSPS, Cry 3A, and determined species identification of positive samples. The use of $P C R-R F$ allows quickly and qualitatively detect the GMO in the research samples. In 2013, the percentage of positive samples was $3.9 \%$ of the total, in $2014-2.3 \%$ and in $2015-3.3 \%$. It is therefore necessary to monitor the vegetable raw and seed material on the presence of genetically modified organisms, to monitor the situation on GMO in Ukraine, because the problem of biosafety and the evaluation of the potential risks from their use is not studied.
\end{abstract}

Key words: safety of vegetable raw, genetically modified organisms, transgenic plants, biotechnology, polymerase chain reaction, PCR RT.

\section{Вступ}

Одним із проблемних питань у формуванні механізмів розвитку екологічно безпечного довкілля $є$ поширення генетично модифікованих організмів (ГМО). Використання методів генної інженерії у сільському господарстві, аграрній промисловості і продовольстві створили нові можливості для виробництва продуктів харчування та кормів для задоволення постійно зростаючих потреб населення у світі. Проте, думки вчених щодо переваг та ризиків генної інженеpiї різні. Тому сьогодні особливо гостро стоїть питання непередбачуваних наслідків і загроз для здоров'я людини та довкілля, пов'язаних з ГМО (Туmochko, 2007; Rudyshyn, 2011).

Наприкінці 1980-х років американською фірмою Monsanto було розроблено перші трансгенні продукти, а початком ї масового поширення вважається 1996 рік. 3 того часу посівні площі генетично модифікованих (ГМ) рослин значно збільшилися. За даними Міжнародного інституту зі сприяння сільськогосподарській біотехнології (ISAAA) у 2015 році площі під вирощування генетично модифікованих сільськогосподарських культур у всьому світі збільшилась із 1,7 млн. га в 1996 р. до 179,7 млн. га. Лідерами з розповсюдження трансгенних рослин є США, Канада, Бразилія, Китай, Індія, Аргентина, ПАР, Куба і Південний Судан (Karamazin, 2009).

До 2004 року в Свропейському союзі (СС) діяв неофіційний мораторій на затвердження нових ГМО. У 2004 році в СС створено регуляторну систему 3 питань безпеки, маркування та відстеження ГМО. Зок- рема, там дозволено введення в обіг лише зареєстрованих ГМ-культур, відсотковий вміст яких не перевищує $0,9 \%$. У Свросоюзі ГМ-культури майже не вирощують. Загальна площа посіву ГМ-культур у ЄС складає приблизно 0,06\% сільгоспугідь. Зони, вільні від ГМО - Австрія, Греція, Швейцарія, Польща, Франція.

В Україні вирощування будь-яких трансгенних культур було заборонене і до 2013 року не було зареєстровано жодної ГМ-лінії рослин. У липні 2013 року Державною ветеринарною та фітосанітарною службою України зареєстровано соєвий шрот MON 40-3-2 (Glycine max, Roundup Ready soybean), як генетично модифікований організм - джерело кормів, який внесений до реєстру генетично модифікованих організмів джерел кормів, кормових добавок та ветеринарних препаратів, які містять такі організми або отримані 3 їх використанням, що дає змогу вільного переміщення та транспортування цієї ГМ-лінії по території України. У той самий час у Республіці Білорусь зареєстровано 2 ГМ-лінії сої (GTS 40-3-2, А 2704-12) та 7 ліній кукурудзи (MON810, Bt 11, NK-603, T-25, GA 21, MIR604, MON 863). У Росії офіційно дозволено до використання для виробництва продуктів харчування 18 ліній ГМО: три сорти сої, шість - кукурудзи, чотири - картоплі, та по одному сорту цукрових буряків і рису (Hynzburg and Narodizkii, 2003; Zabolotnyi and Verjovka, 2012).

Враховуючи наявність зареєстрованих ГМ-ліній рослин на території країн, прикордонних із нашою країною і ризик потрапляння їх в Україну та відсутністю науково обгрунтованих висновків щодо безпеки 
здоров'я людей, тварин і довкілля, назріла гостра потреба проведення досліджень продуктів харчування та рослинної сировини на наявність ГМО.

Метою роботи було дослідити та проаналізувати отримані результати, які були проведені в Державному науково-дослідному контрольному інституті ветеринарних препаратів та кормових добавок за період 2013 - 2015 років, щодо наявності та розповсюдження ГМ-ліній у рослинній сировині, що надходили від господарств різної форми власності.

\section{Матеріал і методи досліджень}

Дослідження рослинної сировини на наявність ГМО проводили методом полімеразної ланцюгової реакції у режимі реального часу (ПЛР-РЧ) шляхом встановлення в них цільових послідовностей промотора $35 \mathrm{~S}$ вірусу мозаїки цвітної капусти (CaMV), промотора FMV i (або) термінатора NOS (T-NOS) T1 плазміди Agrobacterium tumefaciens, Pat, EPSPS, Cry $3 \mathrm{~A}$, а також проведено видову ідентифікацію позитивних зразків.

Для проведення досліджень були використані діагностичні набори $3 \mathrm{AO}$ «Синтол» (Росія) та RBiopharm AG (Німеччина): тест-системи «35S/NOS скрининг», «Растение/35S+FMV/NOS скрининг», «Соя /35S+FMV/NOS скрининг», «АмплиСенс ГМ соя линии-FL», «Соя GTS 40-3-2 идентификація», «Рапс/Pat/EPSPS/NOS скрининг», «Картофель/ Cry 3A скрининг», SureFood PREP Plant, SureFood GMO Screen 35S+NOS+FMV. Виявлення цільових послідовностей проводили на ампліфікаторі АНК-32.

Для дослідження на наявність ГМО надходили такі зразки рослинної сировини: кукурудза, пшениця, соняшник, соя, ріпак, ячмінь, жито, гречка, картопля. У 2013 році на наявність ГМО було перевірено 307 зразків, і відсоток позитивних проб становив 3,9\% від загальної кількості. Позитивні проби виявили при дослідженні кукурудзи та ріпаку. Із 75 проб ріпаку в 1,3\% було виявлено ГМ джерела, а із 38 зразків кукурудзи - у $28,9 \%$.

У 2014 році кількість дослідних зразків збільшилась до 428 і відсоток позитивних становив 2,3\% від загальної кількості. Позитивні проби виявили при дослідженні сої, кукурудзи та ріпаку. Із 55 зразків сої у 12,7\% було виявлено ГМ джерела, з 58 зразків кукурудзи - у 3,5\%, з 119 зразків ріпаку - у 0,8\%.

У 2015 році кількість дослідних зразків становила 275 і відсоток позитивних становив 3,3\% від загальної кількості. Позитивні проби виявили при дослідженні сої та ріпаку. Із 48 зразків сої у 4,2\% було виявлено ГМ джерела, а з 80 зразків ріпаку - у 8,8\%.
У зразках сої було ідентифіковано сою лінії Соя GTS 40-3-2.

Оскільки проблема біобезпеки і оцінки потенційних ризиків від використання трансгенних рослин ще остаточно не вивчена, тому необхідно проводити постійний моніторинг рослинної сировини та посівного матеріалу на наявність генетично модифікованих організмів, щоб простежити ситуацію щодо ГМО в Україні.

\section{Висновки}

Використання ПЛР-РЧ дає можливість швидко і якісно виявити ГМО в досліджуваних зразках. Сьогодні найбільше трансгенних рослин виявлено у кукурудзі, сої та ріпаку. Отримані позитивні результати вказують на те, що в Україні циркулюють ГМ рослини.

Перспективи подальших досліджень. Проводити постійний моніторинг рослинної сировини на наявність трансгенних рослин.

\section{Бібліографічні посилання}

Tymochko, T. (2007). Biobezpeka v Ukraini: pohlyad hromadskosti: henetychno modyficovani orhanismy: «za» i «proty». Ecolohichnyi visnyk. 2, 5-6 (in Ukrainian).

Rudyshyn, S.D. (2011). Transhenni roslyny i problema biobezpeky (2011). Zbirnyk naukovych statei «IIIho Bseukrainskoho ziizdu ekolohiv z miznharodnou uchastu». Vinnyzja. 1, 250-253 (in Ukrainian).

Karamazin, Yu.A. (2009). Some aspects of foodand environmental security in the context of the revival of Ukraine Ukrainian village. Mykrovolnovye tekhnolohyy vnarodnom khoziajstve. Vnedrenye. Problemy. Perspek. 7-8, 99-105 (in Russian).

Zabolotnyi, D.I., Verjovka S.V. (2012) Transhenni bilky u GMO-vmisnych productach charchuvannja: ozinka ryzyku: [chynnyky ryzyku vzhyvannja GM productiv charchuvannja]. Zhurnal Nationalnoii akademii medychnych nauk Ukrainy. 18(3), 379-383 (in Ukrainian).

Hynzburg, A.L., Narodizkii, B.S. (2003). Podchody k ozenke biobezopasnosti genetichesky modyfizirovannych mikroorhanizmov, ispolzovannych $\mathrm{v}$ pischevoi productzii. Zb. trudov 7ho vserosiiskoho konhresa «Zdorovoe pitanie naselenija Rosii». Moskva, 123-124 (In Russian).

Стаття надійшла до редакиії 29.09.2016 